ORIGINAL ARTICLE

\title{
Identifying indicators of defensive activity in narration about important interpersonal relations
}

\author{
Emilia Soroko \\ Clinical and Health Psychology Unit, Institute of Psychology, Adam Mickiewicz University, Poznan, Poland
}

BACKGROUND

One of the main components of psychological conversation that influence communication is psychological defensiveness. In the paper I propose processual - situational understanding of defensiveness, and its measurement based on coding system. Preliminary results on link between personality traits and defensiveness in people's narratives are presented as well.

\section{PARTICIPANTS AND PROCEDURE}

To test proposed coding system, study was conducted with participants presenting different levels of personality organization's (borderline: $n=35,20$ women, $M=26.09$, $S D=4.82$, neurotic: $n=29,24$ women, $M=25.90, S D=5.25$, integrated: $n=31,26$ women, $M=21.94, S D=1.69)$. Correlation method was applied (Borderline Personality Inventory, Neuroticism Scale, Emotion Control Inventory), as well as narrative's interviews. Participants' statements were coded by competent judges (defensiveness and coherence of narratives), and by automatic lexical analyses (descriptive indicators).
RESULTS

Results indicate that proposed defensiveness coding system is a set of heterogeneous indicators, and four groups of indicators could be extracted. Correlations between those indicators and expression control (positive relation), and coherence of narratives (negative relation). Moreover, differences between borderline participants and neurotic ones emerged.

\section{CONCLUSIONS}

Proposed coding system seems to be a heterogeneous but useful tool for assessing defensiveness during psychological interviews. It could be applied as an element of a procedural control measures, directed to test the reliability of psychological conversation.

\section{KEY WORDS}

defensive mechanisms; clinical interview; content analysis; personality disorders

CORReSPONDing Author - Emilia Soroko, Clinical and Health Psychology Unit, Institute of Psychology,

Adam Mickiewicz University, 89 Szamarzewskiego Str., 61-568 Poznan, Poland, e-mail: soroko@amu.edu.pl Authors' Contribution - A: Study design · B: Data collection · C: Statistical analysis · D: Data interpretation ·

E: Manuscript preparation · F: Literature search · G: Funds collection

TO CITE THIS ARTICLE - Soroko, E. (2014). Identifying indicators of defensive activity in narration about important

interpersonal relations. Current Issues in Personality Psychology, 2(3), 149-163. 


\section{BACKGROUND}

In empirical research where qualitative data, such as autobiographical narration of interviewees, are analysed, researchers face the issue of validity of information obtained through interviews. A general question arises: to what extent do the obtained narrations reveal target mental processes, and to what extent are they burdened with distortions, which - hopefully - might be controlled? In the context of qualitative research, the definition of validity and ways to determine it are often modified so that they are better adjusted to the qualitative approach and qualitative data (see more in Stemplewska-Żakowicz, 2005; Silverman, 2008; Kvale, 2011; Flick, 2010).

Validity of the interview method (psychological conversation) is not limited to the issue whether the interview "examines what it is supposed to examine". In the context of the subject of this article, there are other important aspects apart from whether an interview about interpersonal relations (either more or less structured, which allows the researcher to gather information about the relations) makes it possible to gain insight into interpersonal relations and mental representations of these relations. What is also important is the extent to which current interaction is able to evoke a given aspect of the interpersonal relations in the context of that particular interview. Advanced standardization of research settings - although helpful in increasing internal validity - may make it impossible to reveal important mental processes. Therefore, validity is a result of not only the method itself, but also the whole research settings, which tend to be complex. An interview is a form of interaction, which follows social rules (e.g. role asymmetry, self-presentation). During an interview, many complex mental processes take place, e.g. activation of individual autobiographical memories. An interview is also subjected to various instrumental limitations, such as scope of self-awareness, defensiveness, reflexiveness or self-narrative inclination (conf. Soroko, 2013).

Given the above, it becomes clear why qualitative research on validity conceptualization pays attention to: 1) processuality of accuracy, i.e. the need to constantly apply validation procedures (e.g. constant monitoring in order to minimize selective perception and biased interpretation; questioning the aim of research, theorizing and verifying interpretations - Kvale, 2011), and 2) the whole psycho-social background of the research, especially the relations between the observer, the observed phenomenon and the setting of the observation (conf. concept of socalled validity as reflective accountancy, Altheide \& Johnson, after: Flick, 2010).

One of the important components of the complex nature of psychological conversation, related to in- tra-psychic operations expressed verbally, is psychological defensive activity, which will be analysed in this article. We are going to discuss the theoretical background of the 'defensive activity' concept and its significance in the context of narration formulation; we will also discuss construction of a tool used to analyse content, as well as initial research results, which show relations between defensive activity and selected aspects of personality (level of personality organization as presented by Kernberg, control of expressed emotion according to Watson and Greer) and selected parameters of narrations and descriptive text indicators (conf. Soroko, 2014).

\section{DEFENSIVE ACTIVITY - THEORETICAL INTRODUCTION}

In clinical psychology, interest in mental defences is still alive (Bond \& Perry, 2004; Hibbard, Porcerelli, Kamoo, Schwartz, \& Abell, 2010; Kramer, de Roten, Perry, \& Despland, 2013; Sinha \& Watson, 2004). Defensive mechanisms (and/or styles of coping) are often defined as automatic psychological processes which protect an individual from fear and awareness of internal or external stressors. Individuals are usually unaware of these ongoing processes. In more advanced theoretical discussions, defensive mechanisms and coping methods are, however, differentiated. It is mainly believed that coping is an adaptation process, which enables an individual to adapt to goals, whereas defensive mechanisms are connected with an imperative to reduce distress and distort reality (Cramer, 2009; Haan, 1965; Kramer, 2010). In other words, coping is proactive, while defensive mechanisms are triggered as a response to impulse activation, which would lead to a sense of intra-mental threat and fear. Current research on conceptualizations of defences proves, however, that a defensive mechanism does not need to become a response to an internal conflict or fear, but also frustration, stress, crisis, unpleasant affect, threatened self-esteem or lack of security (Hentshel, Draguns, Ehlers, \& Smith, 2004; Kline, 2004; Draguns, 2004). Defences are aimed at self-protection, and are related to self-theories (the more rigid are the theories, the more likely they are to evoke defences, Dweck \& Elliott-Moskwa, 2010), self-esteem and emotion regulation (Cramer, 2009; Kernis, Lakey, \& Heppner, 2008). According to Feldman Barret et al. (2002, p. 3), defensive mechanisms may be treated as motivated cognitive-behavioural strategies, which protect the self from the expected threat, maintain or increase self-esteem, reduce negative affect and maintain positive representations of parental figures.

In the literature, there are two main approaches related to mental defences. On one hand, there is a typological approach - identifying and classifying defences - that shows various ways in which defensive 
operations (defensive functioning) may take place, their various forms and transformations. Typologies may include a selection of relatively unconnected defences (defensive mechanisms) or place them in dimensions from less to more mature (Perry \& Henry, 2004; Vaillant, 1994). Such an approach helps to order and systematize defensive operations, but it also has some limitations in clinical practice, such as low practicality in intervention forming (conf. Gold \& Castillo, 2010), although it should be mentioned that in a psycho-dynamic approach, a precise diagnosis of the type of defences is a key step in a general diagnosis and understanding the patient's problems (conf. McWilliams, 2009; Hibbard et al., 2010). On the other hand, defences can be approached from the processual angle - while reacting to a given external or internal stimulus, an individual uses defensive mechanisms. Their reaction in a particular situation is defensive, which leads to disturbances in the process of experience processing (see e.g. Kramer, 2010; Górska, 2013).

These approaches may be completed with a third approach: dimensional. It sees defensiveness as a relatively constant value, e.g. specific types of defensive mechanisms, intensity or frequency of defensive reaction may contribute to more or less defensive functioning or create such a personal predisposition which may be treated as relatively independent of the situation. For example Feldman Barret et al. (2002) identify general, non-specific defensive activity as a reaction to perceived threat to self, which is defined as external manifestation common to defensive transformations (to be used as defensive mechanisms). In the context of mental health, defensiveness is also conceptualized as an effect of discrepancy between explicit self-esteem measured with self-descriptive tools and implicit self-esteem (Lambird \& Mann, 2006), which can be revealed by low fear indicators in self-descriptive tools or high results for social approval and identified physiological arousal (Myers, 2010; see more in a discussion about illusory mental health, e.g. Shedler, Mayman, \& Melvin, 1993; Weinberger \& Davidson, 1994). One may observe that there is a discrepancy between what is consciously presented and defensively hidden. Defensiveness in the view of cognitive theories highlights the importance of self-serving biases in information processing which allow people to maintain positive self-worth, which results e.g. in rebelling against health recommendations (Crocker, Niija, \& Mischkowski, 2008; Pavey \& Sparks, 2012; Sherman \& Cohen, 2002). In the social context, the perception of whether people could be trusted is important and related to e.g. loneliness, social exclusion, low social-economic status (Brandt \& Henry, 2012) as well as the issue of defensive communication, which leads to destructive cycles of misunderstandings between interaction parties (Becker, Ellevold, \& Stamp, 2008).
These contexts result in different methods of analysing defences. Both supporters of self-descriptive tools (Blaya et al., 2007; Bond, 2004; Davison \& McGregor, 1998; Gould, Prentice, \& Ainslie, 1996; Juni, 1998; Schauenburg, Willenborg, Sammet, \& Ehrenthal, 2007) and narration analyses from interviews and projection tests (Berney et al., 2014; Kramer et al., 2013; Perry, 2001; Cramer, 1998b) focus on identification of defence types (considering maturity hierarchy) and attempts to determine overall defensive functioning scores (Bond \& Perry, 2004; Sinha \& Watson, 2004). Processual analyses of mental defences in specific natural contexts are the least frequent (Feldman Barret et al., 2002). Sometimes circumstances of defensive processes are equated with 'coping' (coping, see e.g. Kramer, 2010; Kramer, De Roten, Michel, \& Despland, 2009), depriving defences of this situation-based parameter, activated by internal and external circumstances.

In this article, the typology of defences was not taken into account; instead, a certain correlation between processual and dimensional approaches was assumed (conf. Feldman Barret et al., 2002). On one hand, a situation-based defensive reaction was analysed, which manifested itself in narration; on the other hand, certain generalizations were sought in terms of non-situational regularities.

Using the term 'defensive activity', we refer to a broadly understood unconscious mental process, in which the individual's reaction to emotional conflicts arising from internal and external stressors is mediated by purposeful - although automatic - defensive mechanisms (see e.g. Berney, de Roten, Beretta, Kramer, \& Despland, 2014). In such defensive activity one can point out the following elements: stimulus, impulse, and resulting arousal, fear which implicates the need to reduce distress and - as a result - defensive reaction (defensive effect manifested externally). Thus, the defensive mechanism and its manifestation as a defensive reaction act as an obstacle in experience processing. A given stimulus cannot be fully recognized cognitively; instead, arousal appears and leads to activation of related self-structures (e.g. self-object dyads according to Kernberg, conf. e.g. Kernberg, 2004). The combination of stimulus and affect becomes distorted, arousal appears, and it becomes impossible to intellectually and consciously process a given experience in language, which is manifested in uttered words and style of narration (conf. Górska, 2013). As Feldman Barret and colleagues (2002) indicate, it is possible to detect traces of defensive processes in the content and structure of narration. They constructed a method to assess verbal defensive mechanisms (defensive verbal behaviour assessment, DVBA), which was based on a bi-dimensional model of defensive processes: 1) awareness of the precipitating threat and 2) the degree of distortion created by the use of cognitive 
strategies. This method is used mainly to assess defensiveness in interviews about stressful situations.

A similar issue of external manifestations of arousal in the form of verbal reactions has been described as verbal defensiveness (Picano, Roland, Williams, \& Rollins, 2006; Shedler et al., 1993), using the analysis of test behaviour in projection methods (namely sentence completion test) (Mandler, Mandler, Kremen, \& Sholton, 1961). In this context, 'defence' means conscious or unconscious effort to omit the content of a verbal stimulus (beginning of a phrase). Verbal defensiveness was identified when e.g. the interviewee omitted important content, misinterpreted the initial phrase, said they weren't able to finish, started to narrate but then stopped, asked for a repetition of the initial phrase, or their reaction time was more than 8 seconds. Both approaches - verbal measurement of defensive behaviours and verbal defensiveness - assume that narration resulting from a stimulus (stressful topic or beginning of a phrase) is analysed. Such a stimulus may evoke a psychological threat, which means that when an interviewee forms an utterance, defensive reactions will be observable.

During a research interview, when a psychologist asks an interviewee to talk about an important interpersonal relationship, the psychological setting is more complex and more similar to a clinical setting. Here are some of the most significant parameters of such a setting: Firstly, an interviewee is encouraged to choose an important person and talk about relations with them (interpersonal relationship from the past). Secondly, during the process of choosing and telling the story - as a reaction to an external request - activation of cognitive-affective structures takes place, understood as representations of relations with an object (conf. Kernberg, 2004; Kernberg \& Caligor, 2005) characterized by a specific level of maturity and ability to encompass subjective experience (intra-psychic relations). Thirdly, the interviewer may co-create the setting for the interviewee to reveal various information about themselves, such as an atmosphere of trust (current interpersonal relations). Defensive activity is an outcome of all these parameters. It consists of biographical and intra-psychic aspects, as well as aspects related to contact, and all these aspects interact with each other (conf. defensive reactions in clinical interviews and the issue of resistance, Gold \& Castillo, 2010; Vehvilainen, 2008). Interpersonal relations with a stranger (such as during a research interview) or psychologist (e.g. in diagnosing or psychotherapy) may be viewed as threatening to the self; therefore one may assume activation of defences. A moderate level of defensive activity is part of the adaptation process related to pressure of everyday interactions (Bowins, 2010). Also, one may expect stronger defences if a difficult or traumatic autobiographical event is to be narrated (Trevithick, 2011). Level of maturity of intrapsychic structures (in a general meaning of level of personality organization) is treated as a factor which determines interpersonal functioning, both current and forming past experiences; its activation may depend to a bigger or lesser extent on the remaining two aspects (conf. Kernberg, 2004; Kernberg \& Caligor, 2005). To sum up the issue of defensive activity, one may say that it is a formal (as said above) manifestation of an internal process (mental, intra-psychic) in verbal utterances and paralinguistic signals that accompany them, which aims at reducing threats to self. This activity's purpose is to eliminate distress related to processing experience evoked by the interview. The topic of the interview may be viewed as a stimulus that activates internal mental content, and not purely as a conversational subject. As a result, free exploration of the subject and communicating about it becomes impossible; please note that communication is secondary to the exploration.

\section{DEFENSIVE ACTIVITY CODING SYSTEM (DACS)}

The presented tool is a narration coding system based on formal characteristics of autobiographical texts resulting from requests to tell a story about an important person. The main aim is to capture various symptoms of defensive activity in such texts. In research where the tool was tested, the instruction (narrative stimulus) was: 'Please tell a story about an important relationship you were involved in recently' and was part of a narrative interview (conf. Soroko, 2014). Generally, the presented coding system may be used for any - initiated by a researcher of clinician - autobiographical story which talks about an important interpersonal relationship. Being a coding system, the tool consists of a certain number of indicators which were construed in such a way that competent, trained judges can use them. The judges know no other information about the interviewee apart from the context of the narration in the interview. Using this coding system requires a verbatim transcription of the utterances of both the interviewer and interviewee, with notes about the following phenomena: filled and empty pauses, emphasis, breakoffs, volume of speech, paralinguistic phenomena.

\section{CONSTRUCTION STAGES AND PSYCHOMETRIC CHARACTERISTICS OF DEFENSIVE ACTIVITY CODING SYSTEM}

Taking into account theoretical discussion about defensive activity as a psychological phenomenon presented in the previous section, direct suggestions in the literature regarding defence activity indicators, the setting of a psychological interview about import- 
ant interpersonal relations and practical experience (research and clinical), four main areas were chosen where defensiveness may be displayed through the style of narration. Based on these four areas, specific indicators were determined. The areas and examples of their indicators are: narration organization (e.g. long pause at the beginning, asking the interviewer about details, engaging the listener in the choice of who and how to narrate); sudden changes in the flow of narration (changes in volume, tone, break-offs of words, sentences); maladjusted narration (too long or too short, lack of narration); and inadequacy of the affect expression (especially in terms of suddenness and inadequacy of the expressed affect (see Table 1).

Initially, 29 indicators were determined and subjected to a pilot assessment. Format of response was finally determined as categorical and dichotomous, expressing either presence of a given indicator (marked as ' 1 ') or lack thereof (' 0 '). The decision not to use a broader scale of points was based on the fact that appearance/lack of appearance of an indicator in the formal layer of text was taken into account - not its intensity throughout the text. It was later on reflected by a high inter-rater agreement (see Table 1). Also, 0-1 scores are not sensitive to the length of narration.

Some indicators are very specific in nature (e.g. "narration starts after a pause longer than 5 seconds", "the interviewee breaks off a sentence and does not go back to that train of thought", "while narrating, the interviewee addresses the interviewer"), and some of them require synthesis of information from the story (e.g. "there are clear contradictions in various parts of the narration", "the interviewee displays affect, but cannot talk about it directly"). Due to the processual aspect of defensiveness, a large proportion of indicators are identified at the beginning of the narration (as a reaction to the narrative stimulus which - as it is assumed - triggers a defensive reaction), some of the indicators are identified in a particular fragment of narration, and others need synthetic insight into the whole narration. For the convenience of assessment, they should be assessed in this order.

Narrations $(N=95)$ obtained as a reaction to the narrative stimulus given above (more about group's characteristics - Table 2) were analysed by min. 2 and max. 5 competent judges. They were $5^{\text {th }}$ year students with training in content analysis and the subject matter (they participated in optional classes).

To determine the final number of items on the scale, empirical data related to inter-rater agreement and comments made during their assessment were used. Inter-rater agreement was established with Krippendorff's $\alpha$ reliability estimate (number of bootstrap samples $=1000$, case of $2-5$ judges used in the computations); it led to eliminating items with an average score lower than 0.40 . It was concluded that low compliance of coding means that this particular indicator is not unambiguous for the coders and does not bode well for subsequent uses of the tool. Consequently, 8 indicators were removed. One of the indicators had no occurrences; therefore its parameters are not determined, but it was added to the current version of the tool for theoretical reasons (conf., Table 1).

Defensive activity is treated as a heterogeneous phenomenon; therefore cumulated point rating scales were not used. Instead, hierarchical analysis of data clustering with Ward's agglomeration method was employed in its binary version in order to analyse which aspects of defensive activity are observable in clusters of data. Four clusters of indicators were determined (DACS-a, DACS-b, DACS-c, and DACS-d), which included 18 out of 20 indicators. Among the remaining two indicators, one ("at the beginning of the interview before the narration starts, the interviewee asks for a repetition of instruction or the topic of narration") was very weakly linked with other clusters, and the other one was not considered because it had no occurrences in the data cluster. Groups distinguished during the cluster analysis consist of very diverse statements, and it is very difficult to determine key names of indicators. Therefore, DACS-a, DACS-b, DACS-c, and DACS-d clusters should be perceived as groups of indicators, although sometimes - for the sake of convenience general labels are used for whole groups of indicators (see Table 1). As intercorrelations show, correlation of clusters is low and there is no interdependence (see Table 3), which confirms low homogeneity of the phenomenon.

Occurrences of particular indicators are not numerous enough to analyse them separately. Moreover, frequency distribution for all separate indicators and sub-scales of clusters are rightward skewed, and the mode in all cases is lack of category occurrence (' 0 '). It confirms the theoretical discussion (the nature of defensive processes) and tool assumptions (to capture as many symptoms of defensiveness as possible), as the tool is designed to capture even slight symptoms of defensiveness (however inconvenient it is from a statistical point of view).

In this context, the following method of score calculation was used: a single occurrence of the indicator with complete agreement of judges was marked as ' 1 ', lack of indicator with judges' agreement was marked as ' 0 '. If the judges differed in their assessments (e.g. two of them chose 0 and two chose 1 ), a value of 0.50 was assigned. When the difference had another value, it was rounded to either 1 or 0 . This way, there were more occurrences in particular sub-scales. Subscales are a sum of an indicator's values (see Table 2).

A low reliability rate reflects the nature of the scale - low frequency of indicator occurrence in subscales and low number of points on the scale.

Coding with the first version of the tool and further comparative and correlation analyses were performed 


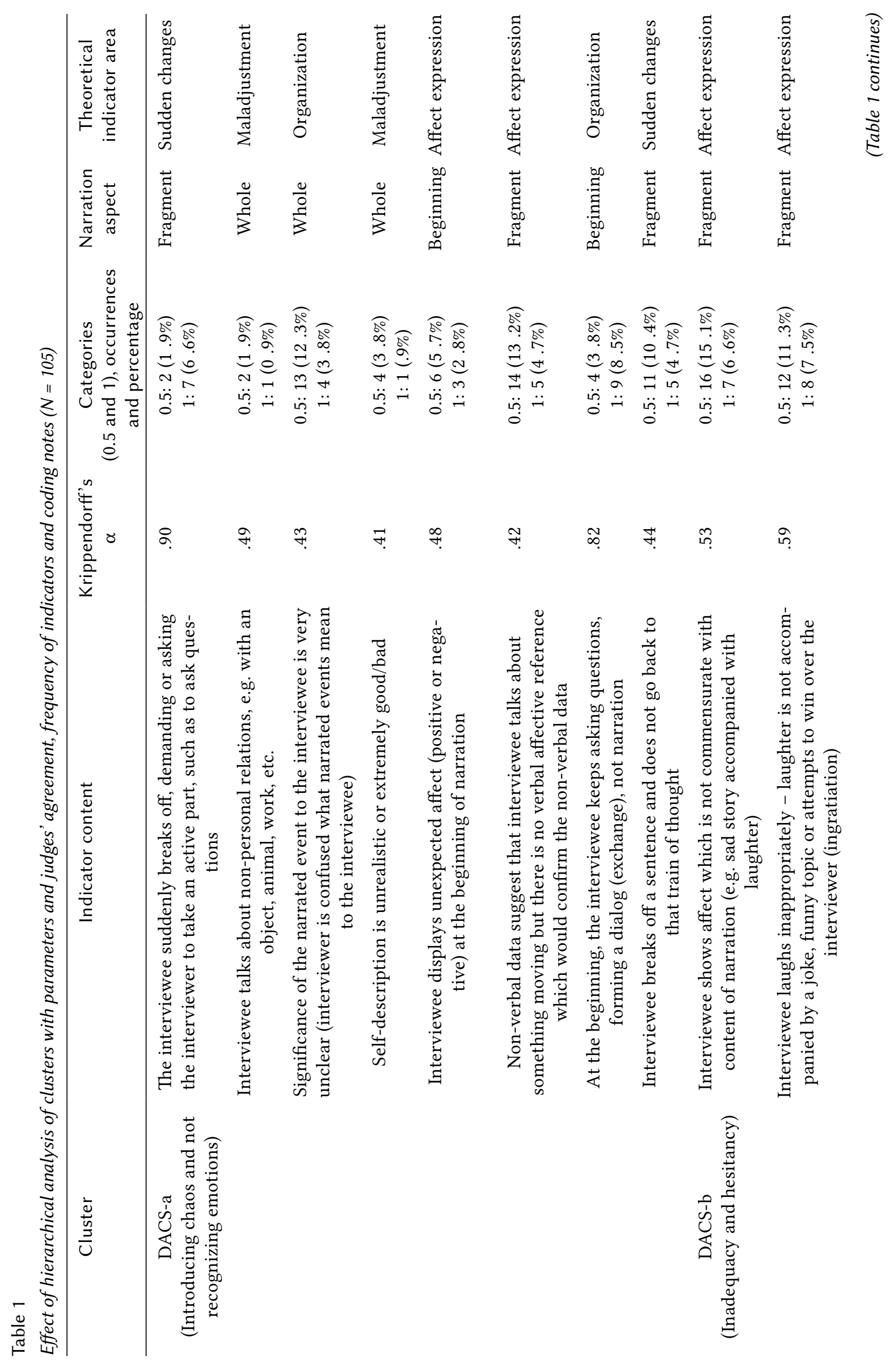




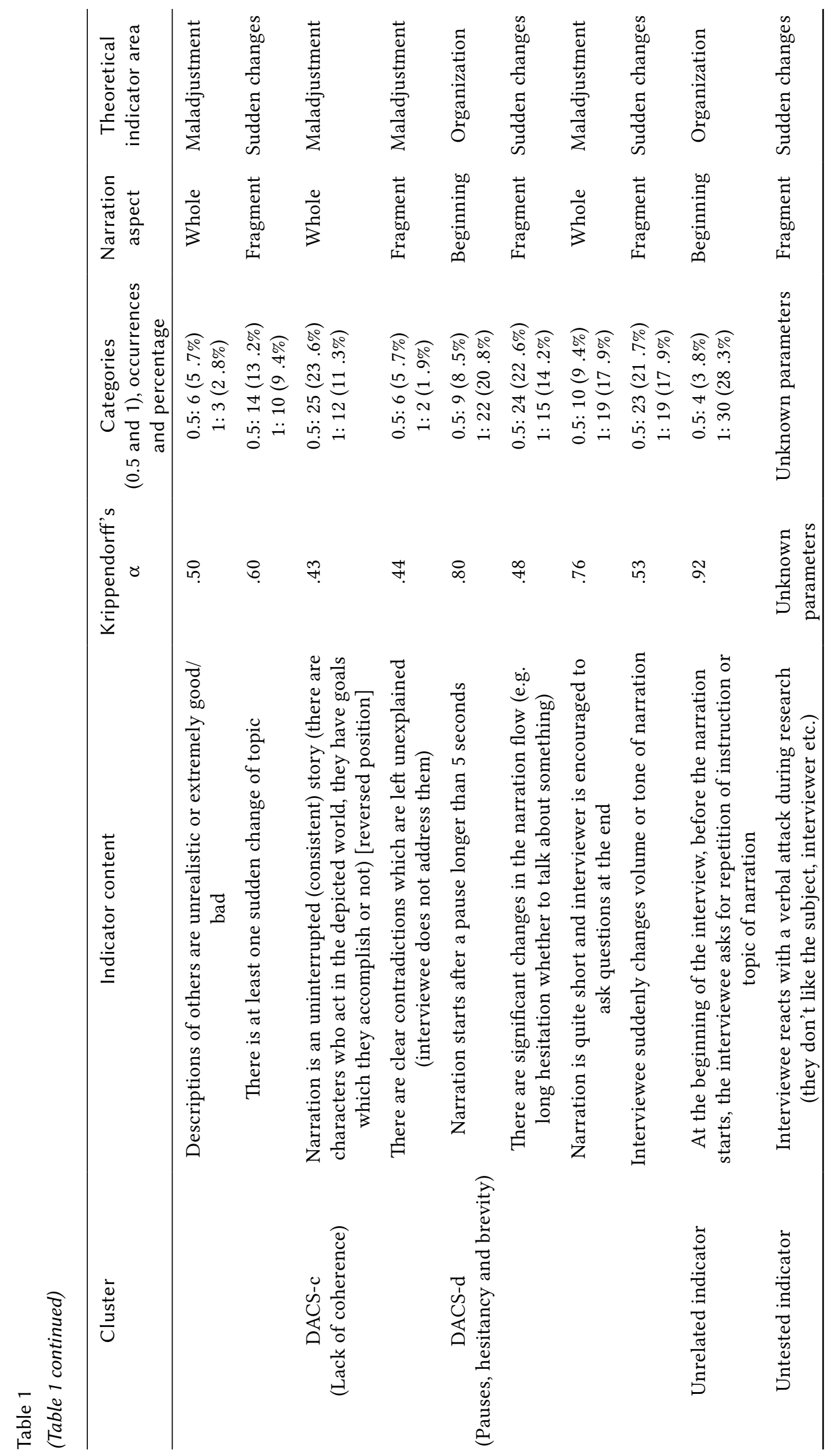


Table 2

Descriptive statistics related to sub-types of defensive activity $(N=105)$

\begin{tabular}{cccccccc}
\hline Cluster & $M$ & $S D$ & Min & Max & Skewness & $\begin{array}{c}\text { Skewness } \\
\text { error }\end{array}$ & $\begin{array}{c}\text { Cronbach's } \\
\alpha\end{array}$ \\
\hline DACS-a & 0.59 & 0.83 & 0 & 3.50 & 1.54 & .24 & .46 \\
DACS-b & 0.49 & 0.70 & 0 & 3.00 & 1.52 & .24 & .47 \\
DACS-c & 0.27 & 0.44 & 0 & 2.00 & 1.85 & .24 & .46 \\
DACS-d & 1.02 & 0.96 & 0 & 3.50 & 0.62 & .24 & .45 \\
\hline
\end{tabular}

Note. DACS-a - 'Introducing chaos and not recognizing emotions'; DACS-b - 'Inadequacy and hesitancy'; DACSc - 'Lack of coherence'; DACS-d - 'Pauses, hesitancy and brevity'.

Table 3

Correlation between results in defensive activity subscales and control of expressed emotions, and intercorrelations of defensive activity scales ( $N=95$, Spearman's rho, one-side correlation)

\begin{tabular}{cccccccc}
\hline & DACS-b & DACS-c & DACS-d & $\begin{array}{c}\text { CECS- } \\
\text { anger }\end{array}$ & $\begin{array}{c}\text { CECS- } \\
\text { depression }\end{array}$ & $\begin{array}{c}\text { CECS-fear } \\
\text { CECS- } \\
\text { total }\end{array}$ \\
\hline DACS-a & $.26^{* *}$ & $.38^{* *}$ & $.35^{* *}$ & $.20^{*}$ & $.19^{*}$ & .15 & $.20^{*}$ \\
DACS-b & & $.24^{* *}$ & .14 & .13 & .12 & .06 & .13 \\
DACS-c & & .15 & $.29^{* *}$ & $.21^{*}$ & .12 & $.25^{* *}$ \\
DACS-d & & & $.20^{*}$ & .13 & $.28^{* *}$ & $.25^{* *}$ \\
\hline
\end{tabular}

Note. DACS-a - 'Introducing chaos and not recognizing emotions'; DACS-b - 'Inadequacy and hesitancy'; DACS-c - 'Lack of coherence'; DACS-d - 'Pauses, hesitancy and brevity'; CECS-anger, CECS-depression, CECS-fear \& CECS-total - subscales and total result of Watson and Greer's Emotional Control Scale.

${ }^{*} p<.050 ;{ }^{*} p<.010$

Table 4

Characteristics of the research group used to determine tool parameters and compare inter-group comparison and correlations in further sections

\begin{tabular}{|c|c|c|c|c|c|c|}
\hline \multirow{3}{*}{$\begin{array}{l}\text { Selection criteria and } \\
\text { characteristics of the } \\
\text { research group }\end{array}$} & \multicolumn{2}{|c|}{$\begin{array}{c}\text { IPO - integrated } \\
\text { personality organization }\end{array}$} & \multicolumn{2}{|c|}{$\begin{array}{c}\text { NPO - neurotic } \\
\text { personality organization }\end{array}$} & \multicolumn{2}{|c|}{$\begin{array}{c}\text { BPO - borderline } \\
\text { personality organization }\end{array}$} \\
\hline & \multicolumn{2}{|c|}{$\begin{array}{l}\text { High score in } \mathrm{BPI} \\
\text { (20 points or more) } \\
\text { and any result in } \\
\text { neuroticism (EPQ-R) }\end{array}$} & \multicolumn{2}{|c|}{$\begin{array}{l}\text { High or moderate result } \\
\text { in neuroticism } \\
\text { (10, } 9,8 \text { or } 7 \text { sten) } \\
\text { and low result in BPI } \\
\text { (below } 20 \text { points) }^{*}\end{array}$} & \multicolumn{2}{|c|}{$\begin{array}{l}\text { Low score in BPI } \\
\text { (below } 20 \text { points) } \\
\text { and low result in } \\
\text { neuroticism } \\
\text { (sten } 1,2,3 \text {, or } 4 \text { ) }\end{array}$} \\
\hline & $n=31$ & $\%$ & $n=29$ & $\%$ & $n=35$ & $\%$ \\
\hline $\begin{array}{c}\text { Clinical/non-clinical } \\
\text { trial }\end{array}$ & $0 / 31$ & & $18 / 11$ & & $26 / 9$ & \\
\hline Women & 26 & 83.90 & 24 & 82.70 & 20 & 57.10 \\
\hline Men & 5 & 16.10 & 5 & 17.20 & 15 & 42.90 \\
\hline Age & $M=21$. & $=1.69$ & $M=25$ & $=5.25$ & $M=26$ & $=4.82$ \\
\hline
\end{tabular}

Note. ${ }^{*}$ Conf. a more detailed explanation and justification of group selection in Soroko, 2014.

with the same group of subjects. The group consisted of 105 persons (see Table 4 for more details), who completed questionnaires, and then took part in psychological interviews about their important interpersonal relations. Interviews were performed according to the narrative interview procedure, where a minimal activity of the interviewer is desired. Autobiographical narration was analysed which followed the narrative stimulus ('Please tell a story about an important relationship you were involved in recently') until a clearly marked code. Interviews yielded narration of average length 808 words $(S D=914 ; \min 137, \max 7140)$.

While selecting subjects, there were two questionnaires used: Borderline Personality Inventory 
(BPI) by Leichsenring (1999) adapted by Cierpialkowska (2001) and Eysenck Personality Inventory (EPQ-R), Eysenck, Eysenck, \& Barrett, 1985) in the Polish adaptation by Brzozowski and Drwal (1995). Both scales have satisfactory reliability and accuracy scores (see: Cierpiałkowska, 2001; Brzozowski \& Drwal, 1995). Additionally, subjects completed CECS (Courtauld Emotional Control Scale) by Watson and Greer, adapted by Juczyński (2001), which was later used for correlation analysis. The group was selected purposefully to encompass three types of personality organization; therefore it included a broad scope of psychological functioning - from healthy operations to severe personality disorders, which increases the desired variance.

\section{CORRELATION BETWEEN DEFENSIVE ACTIVITY AND SELECTED PERSONALITY VARIABLES AND NARRATIONS}

\section{INDICATORS OF DEFENSIVE ACTIVITY VERSUS EMOTION EXPRESSION}

It was assumed that control of expression measured with self-descriptive tools (requiring reflection on one's emotional experience) will be a factor that influences current defensive activity while narrating important relations, which would be captured in the layer of formal text indicators. It was, therefore, expected that certain groups of defensiveness indicators would correlate positively with emotion expression control, understood as revealing emotions such as anger, depression and fear, measured by Watson and Greer's Emotional Control Scale (see Table 3).

The observed correlation coefficients (see Table 3) between clusters of defensive activity indicators and sub-dimensions of emotional control and summarised results show that there are low positive correlations. Controlling anger is related to the highest number of indicator clusters (DACS-a "introducing chaos and not recognizing emotions", DACS-c "lack of coherence", DACS-d "pauses, hesitation and brevity"); depression control correlates slightly with intensity of indicators from DACS-a and DACS-c groups; and fear control is related only to intensity of indicators in DACS-d. Thus, intensity of indicators from DACS-b ("inadequacy and hesitancy") is not related to any sub-dimension of emotional control. A single indicator ("at the beginning of the interview, before the narration starts, the interviewee asks for repetition of instruction or subject of narration") that did not correlate with any empirically distinguished subgroup was treated as a grouping variable which was expected to differentiate emotional control. Using the $t$ test for independent samples, no significant statistical differences were identified in the general emotion- al control and its sub-dimensions in persons with and without this symptom of defensive activity $(p>.050)$.

\section{DEFENSIVE ACTIVITY INDICATORS VERSUS LEVEL OF PERSONALITY ORGANIZATION}

It was also expected that some groups of indicators could be characteristic of persons with various levels of personality organization - borderline, neurotic and integrated. Theoretical knowledge and results of other research on various types and aspects of defensive mechanisms indicate varied defensive activity (Hibbard et al., 2010; Bowins, 2010). It was expected to reveal differences between levels of personality organization also in terms of defensive activity displayed during interviews.

To determine differences between subjects with various levels of personality, a non-parametric Kruskal-Wallis test was used; it proved the existence of statistically valid differences in terms of indicator clusters DACS-a, DACS-b and DACS-c (see Table 5). To obtain a more detailed picture of differences, comparison in pairs with Bonferroni correction was performed. Taking into account sub-scale DACS-a, the borderline personality organization (BPO) group had the highest scores and differed significantly from the neurotic personality organization (NPO) group $(z=-3.16$, $p=.005)$ and integrated personality organization (IPO) group $(z=-3.19, p=.004)$. As for DACS-b, despite differences between the NPO group (highest score) and IPO and BPO groups (whose defensive activity indicators in this subscale had similar values), their corrected significance was above $p=.050$. Taking into account sub-scale DACS-a, the BPO group had the highest scores and differed significantly from the NPO group $(z=-2.75, p=.018)$ and IPO group $(z=-2.44, p=.044)$. It is worth noting that in both cases there was a tendency that people with integrated personality seemed to be placed in the middle - were more similar to neurotics, but had a slightly higher intensity of defensive activity than integrated personalities. Thus, the BPO group differed significantly from the two other groups in terms of intensity of indicators in DACS-a and DACS-c clusters. People with various levels of personality organization did not differ in terms of DACS-c indicators. The indicator "At the beginning of the interview, before the narration starts, the interviewee asks for repetition of instruction or subject of narration" occurred least frequently in the BPO group, and with similar frequency in NPO and IPO subjects.

\section{DEFENSIVE ACTIVITY INDICATORS VERSUS NARRATION COHERENCE AND OTHER ASPECTS OF NARRATION}

A defensive reaction is an interference in current processing of an experience; therefore it was expect- 


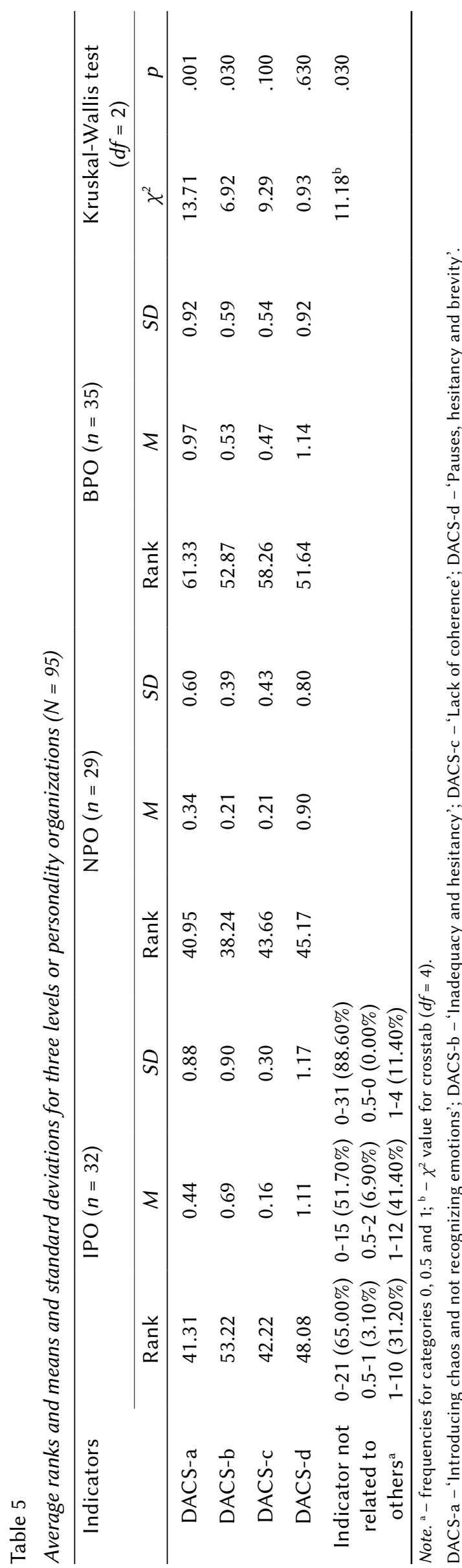

ed that an increase in defensiveness will be accompanied by lower narration coherence. Coherence of narration (Baerger \& McAdams, 1999) is linked with ability to talk about one's own experience, which can be described with the following aspects: orientation (extent to which the narrator places people and action in a specific context - time, place, personal context); structure (extent to which the story is chronological and goal-oriented), affect (extent to which the story expresses emotions in a clear and understandable way); integration (extent to which the narrator can relate the narrated events to a broader perspective, e.g. life, identity) (Table 6).

Indices in DACS-a and DACS-c clusters correlate negatively (low and moderately) with all sub-dimensions of narration coherence and a general score for coherence. Thus, occurrence of these indicators lowers the possibility of obtaining coherent narration in all sub-dimensions.

Relations between selected narration aspects (measured on a lexical level in an automated way - counting the frequency of occurrence of particular textual aspect) and defensiveness were also explored, without assumption of directional relations. The chosen aspects of texts might be related to the processed emotional experience during narration. These aspects were: productivity (total length of narration), nominalization (high indicator means a hindered narration, where the subject tries to generalize instead of report more specific events - Obrębska \& Obrębski, 2010; nouns/verbs), epithetization (an indicator which determines the stylistic quality of the text based on the frequency of adjective usage - Łobos, 2003); adjectives and participles/nouns), narration dynamics (the extent to which the text is expressive, gripping, not monotonous - Nęcki, 2000; verbs/adjectives and participles), focus on self (often measured as an indicator of self-focus and own symptoms - Pennebaker \& Seagal, 1999; pronouns connected with "I", the pronoun "I/me" and verbs in 1st person singular/number of words), and verbal fluency (lack of fluency is specified into various phenomena that disrupt fluency, such as frequent negations, semantic noise and pauses) (Table 7).

There were low and moderate correlations between selected aspects of narration. The results suggest that with higher intensity of DACS-a indicators ("introducing chaos and not recognizing emotions"), there were lower nominalization and epithetization (i.e. unhindered narration and lower stylistic quality), and higher narration dynamics (vividness and expressiveness) as well as lower fluency. The higher the intensity of the DACS-b cluster of indicators ("inadequacy and hesitancy"), the longer was the narration. Higher intensity of the DACS-c cluster of indicators ("lack of coherence") coincides with a stronger self-focus and low fluency of narration. Indicators in the DACS-d cluster ("pauses, hesitancy and brev- 
Table 6

Correlations between defensive activity and coherence ( $N=95$, Spearman's rho, one-sided correlation)

\begin{tabular}{|c|c|c|c|c|c|}
\hline & Orientation & Structure & Affect & Integration & $\begin{array}{c}\text { Overall } \\
\text { narration } \\
\text { coherence }\end{array}$ \\
\hline DACS-a & $-.33^{* *}$ & $-.31^{* *}$ & $-.35^{* *}$ & $-.34^{* *}$ & $-.39^{* *}$ \\
\hline DACS-b & -.02 & -.02 & .03 & .06 & .02 \\
\hline DACS-c & $-.39^{* *}$ & $-.45^{* *}$ & $-.21^{*}$ & $-.30^{* *}$ & $-.39^{* *}$ \\
\hline DACS-d & -.09 & -.05 & -.13 & -.12 & -.13 \\
\hline
\end{tabular}

Table 7

Correlation between defensive activity and selected aspects of narration ( $N=95$, Spearman's rho, two-sided correlation)

\begin{tabular}{ccccccc}
\hline & Productivity & $\begin{array}{c}\text { Nominaliza- } \\
\text { tion }\end{array}$ & Epithets & $\begin{array}{c}\text { Narration } \\
\text { dynamics }\end{array}$ & Self-focus & $\begin{array}{c}\text { Lack } \\
\text { of fluency }\end{array}$ \\
\hline DACS-a & .01 & $-.26^{* *}$ & $-.26^{* *}$ & $.30^{* *}$ & .16 & $.25^{* *}$ \\
DACS-b & $.28^{* *}$ & -.09 & -.01 & .02 & .07 & -.05 \\
DACS-c & -.11 & -.05 & -.06 & .06 & $.27^{* *}$ & $.32^{* *}$ \\
DACS-d & .01 & -.11 & .01 & .09 & .02 & $.51^{* *}$ \\
\hline
\end{tabular}

Note. ${ }^{*} p<.050 ;{ }^{* *} p<.010$.

DACS-a - 'Introducing chaos and not recognizing emotions'; DACS-b - 'Inadequacy and hesitancy'; DACS-c - 'Lack of coherence'; DACS-d - 'Pauses, hesitancy and brevity'.

ity") have a moderately high correlation with lack of fluency. Therefore, indicators of defensive activity (apart from the DACS-b cluster) co-occur with lack of fluency. Particular clusters of defensive activity indicators are linked with specific lexical aspects of narration, which indirectly confirms specificity (dissimilarity) of defensive activity indicators on a lexical level.

\section{DISCUSSION AND LIMITATIONS}

Defensive activity whose indicators were captured in narration about important interpersonal relations is a very heterogeneous phenomenon. Indicators pertain to certain phenomena related to organizing, expressing affect, maladjustment or sudden changes in the story, which occur in fragments of narrations (especially at the beginning) and in the whole body of narration. These indicators may occur once - if the defence was effective, there is no need to repeat the defensive activity. Therefore, we have obtained a low frequency of individual indicators, which means that not every indicator was tested. The presented list of indicators may be used in a clinical setting, e.g. to prepare for the occurrence of above-mentioned phenomena in narrations or to encourage deliberation about co-occurrence of defensive activity indicators. It may also serve as inspiration to broaden the current list and create new indicators related to other thematic contexts, while keeping certain specificity of indicators depending on the context and topic of conversation.

We distinguished certain sub-groups (clusters) of indicators, which co-appeared in the obtained data. These groups are heterogeneous, which leads to difficulty in obtaining a consistent idea of clusters, low inter-correlations between empirically established clusters, and low reliability of individual clusters of indicators. Employing analysis of clusters forced us to treat the scale as more homogeneous. In further research it is necessary to check the stability of links between these categories.

Taking into account the overall results, the question of "to which extent the presented tool used to measure defensive activity in texts is able to capture a situational reaction", and "to which extent it is an emanation of latent mental characteristics", seems to suggest a situational aspect - defensive activity indicators are expressions of reaction to a relational stimulus, which is triggered in a complex research situation (psychological interview). In further research, this method might be used to determine defensive activity at various stages of the interview, 
which would address the situational aspect better; it would also provide for relational contexts (autobiographical, intra-psychic, current). It also seems that in order to investigate the meaning of various methods of defence, it would be useful to perform qualitative analysis of defensive activity which treats selected indicators as a "barometer" of changes in the processed experience.

Analysing links between defensive activity and control of expressed emotions, narration coherence and descriptive indicators of the texts as well as comparison of defensive activity in persons with various levels of personality organization was aimed at determining the reliability of the tool. Investigating links between defensive activity and control of expressed emotions, we observed a correlation between selected sub-groups of indicators and control of fear, depression and anger. One may say that each of these emotions co-occurred with a slightly different configuration of indicators, which proves a certain specificity of the selected subgroups (clusters) of defensive activity. Indicators for pauses, hesitancy and brevity are linked with fear control, while indicators for "lack of coherence" and "introducing chaos and not recognizing emotions" are related to anger and depression control.

Investigating differences between levels of personality organization and clusters of indicators, it was observed that indicators in two clusters (DACS-a and DACS-c) visibly differed in terms of borderline personality type versus neurotic and integrated. This indicates that the relational issue in these groups is coped with differently. In BPOs, there was more frequent activation of defences from DACS-a and DACS-c clusters; their narrations were more chaotic, unstable in terms of affect and less coherent. Research on narration deficits in persons with personality disorders suggested lower coherence and imprecise affect (conf. e.g. Dimaggio, Semerari, Carcione, Nicolo, \& Procacci, 2007; Dimaggio et al., 2003).

Negative correlations (weak, but systematic) between narration coherence (both overall and in particular subdimensions) and intensity of indicators from two clusters (DACS-a and DACS-c) suggest that usage of certain forms of defensive activity is linked to weaker coherence of narration. As Nelson, Bein, Huemer, Ryst, and Steiner, 2009 suggest, talking about stressful events in a chronological sequence (which is a key element of narration coherence) is negatively linked with defensive avoidance of the experienced affect. Correlations between selected descriptive indicators of the texts and certain clusters of defensive activity indicators suggest that there is an interdependence between the level of lexical analysis of the narration (words used and their frequencies) and structural-formal level of narration (conf. Lemke, 1998).

\section{CONCLUSIONS}

The presented scale serves as a tool to measure defensive activity; it has many imperfections related to psychometric parameters (mainly: agreement among judges is varied; reliability of subscales is low, although justified; indicators have so far been tested in only one study), and there are still unanswered questions of ontological and epistemological nature (mainly: what is the nature of defensive activity identified in interviews in the formal text layer - situational or personality-related?). For these reasons, I suggest viewing the presented material as a development stage of the method to monitor aspects which influence the broad issue of psychological interview reliability. Also, the presented work highlights the need to investigate the reliability of qualitative methods for obtaining data in research and psychological practice, which would provide for intra-psychic processes as factors that may influence the final effects of the method.

The studies presented here are part of a larger research project, supported by the KBN/NCN under grant no. NN106 052537: "Level of utterances' narrativity and types of self-narrative at different levels of personality organization".

\section{References}

Baerger, D. R., \& McAdams, D. P. (1999). Life story coherence and its relation to psychological well-being. Narrative Inquiry, 9, 69-96.

Becker, J. A. H., Ellevold, B., \& Stamp, G. H. (2008). The creation of defensiveness in social interaction ii: a model of defensive communication among romantic couples. Communication Monographs, 75, 86-110. DOI: 10.1080/03637750701885415

Berney, S., de Roten, Y., Beretta, V., Kramer, U., \& Despland, J. N. (2014). Identifying psychotic defenses in a clinical interview. Journal of Clinical Psychology, 70, 428-439. DOI: 10.1002/jclp.22087

Blaya, C., Dornelles, M., Blaya, R., Kipper, L., Heldt, E., Isolan, L., \& Bond, M. (2007). Brazilian-Portuguese version of defensive style questionnaire-40 for the assessment of defense mechanisms: construct validity study. Psychotherapy Research, 17, 261-272. DOI: 10.1080/10503300500485581

Bond, M. (2004). Empirical studies of defense style: relationships with psychopathology and change. Harvard Review of Psychiatry, 12, 263-278. DOI: 10.1080/10673220490886167

Bond, M., \& Perry, J. Ch. (2004). Long-term changes in defense styles with psychodynamic psychotherapy for depressive, anxiety, and personality disorders. American Journal of Psychiatry, 161, 1665-1667. 
Bowins, B. (2010). Personality disorders: a dimensional defense mechanism approach. American Journal of Psychotherapy, 64, 153-169.

Brandt, M. J., \& Henry, P. J. (2012). Psychological defensiveness as a mechanism explaining the relationship between low socioeconomic status and religiosity. International Journal for the Psychology of Religion, 22, 321-332. DOI: 10.1080/10508619.2011.646565

Brzezińska, A., \& Brzeziński, J. (2004). Skale szacunkowe w badaniach diagnostycznych [Rating scales in diagnosis]. In: J. Brzeziński (ed.), Metodologia badań psychologicznych. Wybór tekstów [Methodology of psychological research] (pp. 232-306). Warszawa: PWN.

Cierpiałkowska, L. (2001). Adaptacja Kwestionariusza Osobowości Borderline F. Leichsenringa [Leichsenring' s Borderline Personality Inventory]. Unpublished manual.

Cramer, P. (1998a). Defense mechanisms manual. Retrieved from: http://web.williams.edu/Psychology/Faculty/Cramer/cramer.html [29.04.2014]

Cramer, P. (1998b). Defensiveness and defense mechanisms. Journal of Personality, 66, 879-894.

Cramer, P. (2009). Seven pillars of defense mechanism theory. Paper presented at the Annual Meeting of the Rapaport-Klein Study Group, Austen Riggs Center, Stockbridge, Massachusetts.

Crocker, J., Niija, Y., \& Mischkowski, D. (2008). Why does writing about important values reduce defensiveness? Psychological Science, 19, 740.

Davison, K., \& McGregor, M. W. (1998). A critical appraisal of self-report defense mechanism measures. Journal of Personality, 66, 965-992.

Dimaggio, G., Salvatore, G., Azzara, C., Catania, D., Semerari, A., \& Hermans, H. (2003). Dialogical relationships in impoverished narratives: from theory to clinical practice. Psychology and Psychotherapy: Theory, Research and Practice, 76, 385-409.

Dimaggio, G., Semerari, A., Carcione, A., Nicolo, G., \& Procacci, M. (2007). The perpetuation of personality disorders: a model. In: G. Dimaggio, A. Semerari, A. Carcione, G. Nicolo, \& M. Procacci (eds.), Psychotherapy of personality disorders metacognition, states of mind and interpersonal cycles. London; New York: Routledge.

Draguns, J. G. (2004). Defense mechanisms in the clinic, the laboratory, and the social world: toward closing the gaps. In: U. Hentschel, G. Smith, J. G. Draguns, \& W. Ehlers (eds.), Defense mechanisms. New York: Elsevier.

Dweck, C. S., \& Elliott-Moskwa, E. S. (2010). Self-theories: the roots of defensiveness. In: J. E. Maddux, \& J. P. Tangney (eds.), Social psychological foundations of clinical psychology. New York: Guilford Press.

Eysenck, S. B. G., Eysenck, H. J., \& Barrett, P. (1985). A revised version of the psychoticism scale. Personality and Individual Differences, 6, 21-29.
Feldman Barret, L., Williams, N. L., \& Fong, G. T. (2002). Defensive verbal behavior assessment. Personality and Social Psychology Bulletin, 28, 776788.

Flick, U. (2010). Jakość w badaniach jakościowych [Quality in qualitative research]. Warszawa: Wydawnictwo Naukowe PWN.

Gold, S. N., \& Castillo, Y. (2010). Dealing with defenses and defensiveness in interviews. In: D. L. Segal, \& M. Hersen (eds.), Diagnostic interviewing. New York: Springer.

Gould, J. R., Prentice, N. M., \& Ainslie, R. C. (1996). The splitting index scale: construction of a scale measuring the defense mechanism of splitting. Journal of Personality Assessment, 66, 414-430.

Górska, D. (2013). Emotions (un)expressed in words: referential activity in borderline personality disorder. Acta Neuropsychologica, 11, 143-160.

Haan, N. (1965). Coping and defense mechanisms related to personality inventories. Journal of Consulting Psychology, 29, 373-378.

Hentshel U., Draguns, J. G., Ehlers, W., \& Smith, G. (2004). Defense mechanisms: current approaches to research and measurement. In: U. Hentschel, G. Smith, J. G. Draguns, \& W. Ehlers (eds.), Defense mechanisms. New York: Elsevier.

Hibbard, S., Porcerelli, J., Kamoo, R., Schwartz, M., \& Abell, S. (2010). Defense and object relational maturity on Thematic Apperception Test scales indicate levels of personality organization. Journal of Personality Assessment, 92, 241-253. DOI: 10.1080/00223891003670190

Juczyński, Z. (2001). Narzędzia pomiaru w promocji i psychologii zdrowia [Measurement tools in promotion of health psychology]. Warszawa: Pracownia Testów Psychologicznych.

Juni, S. (1998). The defense mechanisms inventory: theoretical and psychometric implications. Current Psychology, 17, 313-332.

Kernberg, O. F. (2004). Borderline personality disorder and borderline personality organization: psychopathology and psychotherapy. In: J. J. Magnavita (ed.), Handbook of personality disorders theory and practice. Hoboken, N.J.: John Wiley.

Kernberg, O. F., \& Caligor, E. (2005). A psychoanalytic theory of personality disorder. In: M. F. Lenzenweger, \& J. F. Clarkin (eds.), Major theories of personality disorders. London: Guilford Press.

Kernis, M. H., Lakey, C. E., \& Heppner, W. L. (2008). Secure versus fragile high self-esteem as a predictor of verbal defensiveness: converging findings across three different markers. Journal of Personality, 76, 477-512. DOI: 10.1111/j.14676494.2008.00493.x

Kline, P. (2004). A critical perspective on defense mechanisms. In: U. Hentschel, G. Smith, J. G. Draguns, \& W. Ehlers (eds.), Defense mechanisms. New York: Elsevier. 
Kramer, U. (2010). Coping and defence mechanisms: what's the difference? - Second act. Psychology and psychotherapy: theory, research and practice, 83, 207-221.

Kramer, U., de Roten, Y., Michel, L., \& Despland, J. N. (2009). Early change in defence mechanisms and coping in short-term dynamic psychotherapy: relations with symptoms and alliance. Clinical Psychology and Psychotherapy, 16, 408-417. DOI: 10.1002/cpp.616

Kramer, U., de Roten, Y., Perry, J. Ch., \& Despland, J.-N. (2013). Beyond splitting: observer-rated defense mechanisms in borderline personality disorder. Psychoanalytic Psychology, 30, 3-15. DOI: 10.1037/a0029463

Kvale, S. (2011). Prowadzenie wywiadów [Conducting interviews]. Warszawa: Wydawnictwo Naukowe PWN.

Lambird, K. H., \& Mann, T. (2006). When do ego threats lead to self-regulation failure? Negative consequences of defensive high self-esteem. Personality and Social Psychology Bulletin, 32, 1177-1187. DOI: 10.1177/0146167206289408

Leichsenring, F. (1999). Development and first results of the Borderline Personality Inventory: a self-report instrument for assessing borderline personality organization. Journal of Personality Assessment, 73, 45-63.

Lemke, J. L. (1998). Analyzing verbal data: principles, methods, and problems. In: K. Tobin, \& B. Fraser (eds.), International handbook of science education. Dordrecht: Kluwer Academic Publishers.

Łobos, A. (2003). Język czasopism i programów telewizyjnych dla dzieci [Language of journals and TV programs for children]. Katowice: Wydawnictwo Uniwersytetu Śląskiego.

Mandler, G., Mandler, J. M., Kremen, I., \& Sholton, R. D. (1961). The response to threat: Relations among verbal and physiological indices. Psychological Monographs: General and Applied, 25, 1-22.

McWilliams, N. (2009). Diagnoza psychoanalityczna [Psychoanalytic diagnosis]. Gdańsk: GWP.

Myers, L. B. (2010). The importance of the repressive coping style: findings from 30 years of research. Anxiety Stress Coping, 23, 3-17. DOI: 10.1080/10615800903366945

Nelson, K. L., Bein, E., Huemer, J., Ryst, E., \& Steiner, H. (2009). Listening for avoidance: narrative form and defensiveness in adolescent memories. Child Psychiatry and Human Development, 40, 561-573. DOI: 10.1007/s10578-009-0144-y

Nęcki, Z. (2000). Komunikacja międzyludzka [Communication between people]. Kraków: Antykwa.

Obrębska, M., \& Obrębski, T. (2010). Charakterystyka wybranych cech wypowiedzi osób chorych na schizofrenię. Analiza porównawcza z wykorzystaniem Wskaźników Stylów Mówienia Suitberta Ertela. Wstępne doniesienie z badań [Characteri- stics of selected features of speech of individuals with schizophrenia. Comparative analysis using the Suitbert Ertel's indicators speaking styles. Preliminary research report]. Current Problems of Psychiatry, 11, 11-19.

Pavey, L. J., \& Sparks, P. (2012). Autonomy and defensiveness: experimentally increasing adaptive responses to health-risk information via priming and self-affirmation. Psychological Health, 27, 259276. DOI: $10.1080 / 08870446.2011 .556251$

Pennebaker, J. W., \& Seagal, J. D. (1999). Forming a story: the health benefits of narrative. Journal of Clinical Psychology, 55, 1243-1254.

Perry, J. Ch. (2001). A pilot study of defenses in adults with personality disorders entering psychotherapy. The Journal of Nervous and Mental Disease, 189, 651-660.

Perry, J. Ch., \& Henry, M. (2004). Studying defense mechanisms in psychotherapy using the Defense Mechanism Rating Scale. In: U. Hentschel, G. Smith, J. G. Draguns, \& W. Ehlers (eds.), Defense mechanisms. Theoretical, research and clinical perspectives (Vol. 126, pp. 165-192). London: Elsevier.

Picano, J. J., Roland, R. R., Williams, T. J., \& Rollins, K. D. (2006). Sentence Completion Test Verbal Defensiveness as a predictor of success in military personnel selection. Military Psychology, 18, 207-218.

Schauenburg, H., Willenborg, V., Sammet, I., \& Ehrenthal, J. C. (2007). Self-reported defense mechanisms as an outcome measure in psychotherapy: a study on the German version of the Defence Style Questionnaire DSQ 40. Psychol Psychother, 80, 355-366. DOI: 10.1348/147608306X146068

Shedler, J., Mayman, M., \& Melvin, M. (1993). The illusion of mental health. American Psychologist, 48, 1117-1131.

Sherman, D. K., \& Cohen, G. L. (2002). Accepting threatening information: self-affirmation and the reduction of defensive biases. Current Directions in Psychological Science, 11, 119.

Silverman, D. (2008). Prowadzenie badań jakościowych [Conducting qualitative research]. Warszawa: Wydawnictwo Naukowe PWN.

Sinha, B. K., \& Watson, D. C. (2004). Personality disorder clusters and the Defence Style Questionnaire. Psychology and Psychotherapy: Theory, Research and Practice, 77, 55-66.

Soroko, E. (2013). Kwestionariusz inklinacji autonarracyjnej (IAN-R) - pomiar skłonności do narracyjnego opracowywania i relacjonowania doświadczenia [Tendency to narrative elaboration and narrative reporting of experience]. Studia Psychologiczne, 51, 5-18.

Soroko, E. (2014). Aktywność autonarracyjna osób z różnym poziomem organizacji osobowości. Opowieści o bliskich zwiqzzkach [Self-narratives of people with different levels of personality organiza- 
tion. Stories about close relationships]. Poznań: Wydawnictwo Naukowe UAM.

Stemplewska-Żakowicz, K. (2005). Metoda wywiadu w psychologii [Psychological interview]. In: K. Stemplewska-Żakowicz, \& K. Krejtz (eds.), Wywiad psychologiczny - wywiad jako postępowanie badawcze [Psychological interview - an interview as a research procedure]. Warszawa: Pracownia Testów Psychologicznych.

Trevithick,P.(2011). Understanding defences and defensiveness in social work. Journal of Social Work Practice, 25, 389-412. DOI: 10.1080/02650533.2011.626642

Vaillant, G. E. (1994). Ego mechanisms of defense and personality psychopathology. Journal of $A b-$ normal Psychology, 103, 44-50.

Vehvilainen, S. (2008). Identifying and managing resistance in psychoanalytic interaction. In: A. Perakyla, Ch. Antaki, S. Vehvilainen, \& I. Leudar (eds.), Conversation analysis and psychotherapy. Cambridge: Cambridge University Press.

Weinberger, D. A., \& Davidson, M. N. (1994). Styles of inhibiting emotional expression: Distinguishing repressive coping from impression management. Journal of Personality, 62, 587-613. 